\title{
Modern Business Activities and Firms' Performance: The Case of Corporate Social Responsibility, Evidence from the Greek Listed Firms in the Athens Stock Exchange
}

\author{
Aristeidis Papagrigoriou1,2, Petros Kalantonis ${ }^{1,2}$, Chrysoula Matsali1, Panagiotis Kaldis ${ }^{3}$ \\ ${ }^{1}$ Department of Tourism Management, University of West Attica, Athens, Greece \\ ${ }^{2}$ School of Social Sciences, Hellenic Open University, Patra, Greece \\ ${ }^{3}$ Department of Wine, Vine and Beverage Sciences, University of West Attica, Athens, Greece \\ Email: papagreg@uniwa.gr, pkalant@uniwa.gr,xmatsali@uniwa.gr, pkaldis@uniwa.gr
}

How to cite this paper: Papagrigoriou, A., Kalantonis, P., Matsali, C., \& Kaldis, P. (2021). Modern Business Activities and Firms' Performance: The Case of Corporate Social Responsibility, Evidence from the Greek Listed Firms in the Athens Stock Exchange. Modern Economy, 12, 429-451. https://doi.org/10.4236/me.2021.122022

Received: January 7, 2021

Accepted: February 23, 2021

Published: February 26, 2021

Copyright $\odot 2021$ by author(s) and Scientific Research Publishing Inc. This work is licensed under the Creative Commons Attribution International License (CC BY 4.0).

http://creativecommons.org/licenses/by/4.0/

\begin{abstract}
The motive for this research was an ongoing debate over whether firms' mission is solely to make profits or should contribute to the social and environmental concerns that accompany the practice of Corporate Social Responsibility (CSR). More and more firms are reporting CSR activities either because due to the legislative framework or cause of the benefits derived from the engagement with sustainability goals. Corporate Social Responsibility constitutes an activity in the modern business environment and attracts the interest of the stakeholders. It is related to the firms' activities for the protection of the environment and contributes to the society since firms offer resources in the society, take care of employees' improvement, become respectful to their customers and co-operate with suppliers who are also oriented to the responsibility. Through this research, we investigate the relationship between CSR activities and Corporate Financial Performance (CFP) during 2016-2017 in Greece. Our sample consisted of companies, listed on the Athens Stock Exchange, during the years of capital controls implementation and before the end of the bailout memorandum with EU (in August 2018). We examine the effect of CSR disclosure on firms' financial performance and also if the better financial performing firms tend to issue significantly more CSR reports. The results reveal that there is no significant correlation between CSR and Corporate financial performance though a high percentage of the sample discloses CSR activities.
\end{abstract}




\section{Keywords}

Corporate Social Responsibility (CSR), Corporate Financial Performance (CFP), CSR Pillars

\section{Introduction}

Corporate Social Responsibility has been related to modern business environment as it is noticed by Verma (2015), who specified the demand for CSR disclosure for the stakeholders and the need for more reliable indicators for the CSR activities and strategies. In a prior study Davis (1967) recognized the relation between social responsibility and modern business development focusing on the managerial responsibilities. The purpose of this study is to investigate the effect of Corporate Social Responsibility on the firm's financial performance in 2016 when Greek firms adopted the relevant legal framework. More specifically, according to the amendments of the directives 2013/34/EU/2014 and 2014/95/EU/2014, firms are required to disclose non-financial and diversity information. The directives represent part of a broader effort by the European Council to increase business transparency on social and environmental matters. Thus, non-financial reporting became mandatory for large public-interest companies with more than 500 employees which cover approximately 6.000 large companies and groups across the EU, including listed companies, banks, insurance companies, and other companies designated by national authorities as public interest entities. We focus on the years 2016 and 2017 because those are the first two years of the implementation of the above adoption and it was crucial to estimate the behavior of firms that have the obligation to follow this legal framework in conjunction with the relevant CSR practices.

The most relevant approach for CSR is related to the stakeholders. Nikolova and Arsic (2017)—following this approach-classified the relevant theories into four groups: 1) Instrumental theories, in which the corporation is an instrument for wealth generation and its social activities consist only a method to achieve economic results; 2) Political theories, which cover the power of corporations in society and the good use of this power in the political field; 3) Integrative theories, in which the organization is focused on the fulfillment of social demands; and 4) Ethical theories, based on the ethical responsibilities of corporations to society. No matter the reason for which companies implement CSR activities, we investigate the relationship between CSR and the performance of firms and furthermore to clarify whether the frequency of disclosing non-financial reports influences profitability.

In June 2015, a liquidity crisis was triggered by an economic shock. As a result, the government decided on the adoption of capital controls in Greece. Of course, the Greek economy has been stated under financial probation by IMF EU since 2010. In that year, according to Baldwin \& Giavazzi (2015); Hardouve- 
lis \& Gkionis (2016) and Nelson et al. (2015), the size of the budget deficit in Greece became $15.2 \%$ of GDP. Due to the fact of the continuous political changes and the socioeconomic effect of the global financial crisis in Greece, the Greek economy has remained under financial probation, almost, ten years. The period after 2015 was critical for the viability of Greek economy. During that period and specifically in 2016 Greek listed firms should mandatorily disclose CSR reports. In our study, we explore specifically that period (after the adoption of mandatory CSR reporting) contributing in this way in the research literature.

The main scope of this research paper is to examine the effect of CSR on CFP (Corporate Financial Performance) for the years 2016 and 2017. The examined period could be considered more interesting because in 2016, and 2017-despite the fact of the mandatory CSR reporting-firms should manage also the negative consequences of the capital controls. Specifically, the Greek's economy deep recession implied a poor financial performance of firms. In addition to the existent literature, we detect for any significant differences-in the financial performance-related to the CSR activity, in a period that the indicators of firms value and profitability were expected to be remarkably low. We believe that the study of that specific period could differentiate our findings from those of relevant studies.

This study is structured as follows:

At first, we focus on the research relevant literature, mentioning the different findings for the relationship between CSR and CFP. In the next section that we present the proposed research methodology and state our research hypothesis and the variables of CSR and CFP. Then we discuss the results of our analysis and our findings. Last but not least we demonstrate our concluding remarks, the limitations, and further research proposal.

\section{Literature Approaches \& Reviews}

\subsection{Companies' Awareness and Disclosing}

Companies' awareness of the need to disclose the appropriate report regarding their sustainability and the positive correlation between all CSR and CFP variables was supported by Waworuntu et al. (2014). Their aim was to establish the extent and pattern of corporate disclosure in a total population of 40 companies listed in the ASEAN region. Among them, 15 companies provided a separate sustainability report and 19 companies disclosed their CSR policies and activities in a specific section. It was also found that as the number of economic disclosure increase, there was also an increase in the profitability of the firm.

In addition, Li et al. (2013) as well as Platanova et al. (2018) argued that firms that perform well it's more likely to disclose their CSR activities and moreover their quality is better. Li et al. (2013) examined the effect of firm performance on CSR disclosure in terms of disclosure frequency and quality among 1.574 Chinese listed firms in 2008 in China Stock Market. Their results agreed with those Platanova's et al. (2018) who conducted an empirical analysis by using a sample 
consisted of 25 fully-fledged Islamic Banks from GCC countries, namely Bahrain, Saudi Arabia, Qatar, Kuwait, and the United Arab Emirates. This paper examined over the period of 2000-2014 whether the higher level of CSR disclosure indicates the better financial performance of GCC Islamic banks as for now and also in the future. Along with that, they explored whether all the composite dimensions of CSR disclosure have an individual positive impact on the financial performance of GCC Islamic Banks either now or in the future. The findings of this study indicated a positive relationship between the CSR disclosure index and financial performance as well as future performance. Furthermore, no statistically significant relationship between all the individual dimensions of corporate social performance and the financial performance measure has been detected. In other words, any individual composite dimension of CSR disclosure has not a positive impact on the financial performance of GCC Islamic Banks.

Attempting to investigate the impact of corporate social responsibility activities on corporate performance, Kang and Liu (2013), employed a sample of 685 non-financial companies listed on the Taiwan Stock Exchange over the period 2008-2010. An important finding was that the sensitivity of a company's performance to its engagement in CSR activities does not vary with the quantile location of the firm's performance level. That paper also argued a uniformly significant positive relationship between engagement in CSR activities and firm performance. The same result was carried out by Kakakhel et al. (2015) with 15 listed companies from Karachi Stock Exchange in Pakistan, during the time period of 2008-2014, originated from the cement sector. The motivating factor of that study was the utmost importance of the cement industry in Pakistan's economy due to infrastructure development in Pakistan, reconstruction after floods, and destructive earthquakes since is one of the most seismically active countries in the world. In the meantime, the study of Rhou et al. (2016) observed that even with positive CSR activities, if the companies fail to communicate with stakeholders, financial benefits do not occur. The sample was composed of 53 restaurant firms for the years 1992-2012 listed on the US stock market. The study revealed that positive CSR activities add financial value to restaurant companies only if the companies effectively publicize their CSR involvement. Negative CSR activities significantly and adversely affect firm performance as the media expose restaurant companies' socially-irresponsible activities to the public.

\subsection{The Impact of Firms' Ownership and Core Operations on the Relationship between CFP and CSR}

State ownership exerts a moderating effect on the relationship between firm performance and CSR disclosure. China has a special institutional background-the majority of listed companies are SOEs (state-owned enterprises) - and the state as owner often has different goals than private shareholders. The objectives of SOEs include not only profit but also social aims, such as greater employment. Therefore, Li et al. (2013) found weaker the link (between 
firm performance and CSR disclosure) among SOEs enterprises compared with NOEs (non-state-owned) ones.

Another point of view based on whether CSR activities are related to the firms core operations or not and the role played simultaneously by economic conditions on the link between CFP and CSR, was investigated by Lee et al. (2013). U.S restaurant industry for the years 1991-2009 was the sample data for this research. In that study CSR activities were dichotomized based on whether they were related to the firm's core operations or not, providing a more nuanced explanation of how some CSR activities may be more beneficial than others to firm value in hard economic times. Though, according to the findings of that research, NON-OR (non-operation related) and OR (operation related) CSR activities have no significant impact on a firm's performance, the moderating role of economic conditions provides significant results. Thus, during favorable economic conditions NON-OR and OR CSR activities don't add value to their firm's performance while on the contrary during recessionary periods NON-OR CSR activities lead to a decline in firm value and, OR CSR activities appear to help a firm's value.

\subsection{Economic Fluctuations on the Link between CSR and CFP}

Economic and social change was the moderating variable for another research analyzed by Ahamed et al. (2014) for Malaysian firms. Malaysia was chosen due to the fact that it's one of the world's developing countries. The main source of data was taken from three large companies from 2007 to 2011. The time span was critical due to the fact that it was the recovery period from the financial crisis that hit Asian Countries. The results indicated that firms exhibit greater concern to improve financial performance and corporate reputation via increasing their CSR or sustainability report in their annual report. The impact of economic fluctuations on the link between CSR and CFP was also the main objective of the research of Wang et al. (2015). They were seeking to investigate the direction of causality between CSR and CFP and examine whether the relationship between CSR \& CFP is stronger for firms of developed economies than from developing economies. The authors upon completion of the literature retrieval procedure that met specific specifications (such as statistic outcomes, correlation coefficients from different samples, etc.), obtained a total of 119 effect sizes reported in 42 studies. The survey supported that the relationship between CSR \& CFP, based on different measurement strategies of CSR are significantly different. Moreover, the relationship between CSR and CFP is significantly positive and is stronger for firms from developed economies than from developing ones. Besides, their study indicated that subsequent financial performance is positively associated with prior social responsibility.

\subsection{The Contribution of Predicted Benefits and Adoption of CSR Practices on Financial Performance}

Nevertheless, the relationship between CSR and CFP is more complex than pre- 
vious studies have revealed. Saeidi et al. (2014) argue that sustainable competitive advantage, which has been omitted as the final outcome of customer's satisfaction and reputation (Awang \& Jusoff, 2009), is assumed to be another effective mediator in this relationship. The sample consisted of 205 firms from industrial manufacturing firms (57.7\%) and consumer product manufacturing sector $(42.3 \%)$ tests and develops a more complex relationship between CSR and firm performance by including three mediators (customer satisfaction, reputation, and sustainable competitive advantage) as three predicted benefits of CSR. The outcome based on the above three mediators revealed that CSR is positively associated with firm performance and according to the findings, a better reputation and competitive advantage are consequences of increased customer satisfaction after engaging in CSR.

Likewise, a few years later Hategan et al. (2018) investigated if there is a strong correlation between CSR and profit and mostly how companies behave in the periods they have losses, whether they continue to do CSR activities, they reduce activities, or they give them up. Thus CSR is attributed to the concept of "doing good" and profit to the expression of "doing well". The sample consisted of 53 Romanian companies listed at BSE validating two points of view. The first was the impact of "doing well" (profit) over the "doing good" (CSR) and vice versa. The results for the first perspective showed that the odds of doing CSR for the listed companies with profit are 8.31 times greater than the odds of the companies which registered losses. The second perspective analyzes the odds of recording profit for the companies that had CSR resulting they are 14.48 times greater than the odds of companies that did not have CSR activities. Furthermore, it was validated that $33 \%$ of the time, firms that are "doing poorly" continued to have CSR activities, to "do good".

Bhattacharyya \& Rahman (2019) documented that CSR expenditures affect positively the ROA. Nevertheless, Astara et al. (2017) investigated the association between CSR and CFP using a sample of 124 listed companies in the Athens Stock Exchange during the period 2006-2012. Similar to previous studies, in that study was investigated whether the financial performance of firms that reported CSR practices differs significantly from those who didn't report. In other words, they explored if CSR affected firms' financial performance. Generally, the empirical results indicated that CSR is a factor that contributes positively to the financial performance in terms of ROA \& ROE. At the same time, not all the variables of CSR contribute positively to firms' performance. For this purpose, Cho et al. (2019) selected 191 companies listed on the Korean exchange so as to examine as well whether CSR will exert a statistically significant influence on firm profitability, growth, and corporate value. According to the results, a significant positive relationship was observed in the correlation between CSR performance and profitability; while on the contrary, consumer's protection exerted a statistically significant negative influence on corporate value.

An important practice of CSR is of environmental sustainability. Indeed, due to the environmental degradation, there is a constantly increasing pressure for 
firms to adopt environmental sustainability into their strategies (Ntanos et al., 2018; Ntanos et al., 2019; Skordoulis et al., 2020a). This adoption can be achieved through the framework of corporate environmental responsibility (Babiak \& Trendafilova, 2011). Based on the relevant literature, there is evidence that firms' environmental protection strategies that can be included into a CSR framework can increase resource efficiency (Porter \& van der Linde, 1995; Rexhauser \& Rammer, 2014), improve market reputation (Dangelico \& Pontrandolfo, 2015), create new markets (Halila \& Rundquist, 2011) and differentiate firms from their competitors (Skordoulis et al., 2020b). Thus, such strategies are not only positively correlated with financial performance (Albertini, 2013; Koo et al., 2014) but also with the establishment of a sustainable competitive advantage (Aragon-Correa \& Sharma, 2003; Skordoulis et al., 2020c).

Many empirical studies have tested the nature of the relationship between CSR and CFP. However, results have been mixed. In recent studies, scholars have argued that socially responsible corporate behavior varied across countries and appealed for more attention to a cross-national comparison. In total, studies showed that CSR spending did not necessarily guarantee better performance and many mediating variables may exist which affect this relationship. Therefore, CSR is a long-term investment or commitment which all organization should take into consideration and decide wisely the benefits to undertake in line with their corporate mission and vision.

\section{Methodology}

\subsection{Aims and Scope}

The main scope of this paper is to examine the effect of Corporate Social Responsibility on Corporate Social Performance in terms of four main pillars. The term sustainability is actually referring to four distinct areas that influence not only the profitability and growth of firms but also their social and environmental impact.

Our sample consisted of 98 companies listed on the Athens Stock Exchange during the period 2016-2017. More specifically, among the 98 companies, 56\% are from the industrial sector, $24 \%$ consists of companies in the services sector, and the remaining $20 \%$ are commercial firms. Furthermore, financial institutions, banks, and investment, and insurance firms were excluded, cause of the fact that their financial reports are not comparable cause of different structure.

In this paper according to prior studies (Agrawal \& Knoeber, 1996; Florackis et al., 2009; Li et al., 2009), we developed a regression model in which CFP variables appeared as dependent and CSR were stated as independent. After applying the proper statistic analysis, discussing and proposing further research, is stated, underlying also the limitations of the present survey in the last section.

\subsection{Sub-Areas of Corporate Social Responsibility (Four Main Pillars)}

The issue of this paper is to examine the effect of Corporate Social Responsibility 
on Corporate Financial Performance in terms of four main pillars. The term sustainability is actually referring to four distinct areas that influence not only the profitability and growth of firms but also their social and environmental impact.

In 2008, CR Institute in Greece introduced the CR index, the most important international measure of firm's performance in the field of corporate social responsibility. More specifically CR index composes an important evaluation tool for assessing CSR performance in four sub-areas (pillars): Society, Environment, Workplace, and Marketplace. This segmentation of social responsibility was the theoretical framework on which this survey was based.

Moreover, one of the primary goals of corporate social responsibility is the environment. Businesses, regardless of size have large carbon footprints. Any steps they can take to reduce those footprints are considered good for both the company and society. Companies of our data seek on reducing any damaging effects on the environment from their business' processes through activities that may focus on energy use, water use, waste management, recycling, and more specifically on pollution prevention programs and rational using of natural resources.

Another pillar of CSR and one of the last bastions of resistance within corporate social responsibility seems to be the workplace and more specifically the HR department. So the first question comes down to how employees are dealt with and whether they feel a sense of motivation and pride in working for the company. This mostly depends on remuneration, employee development, work-life balance, health and safety, diversity, and consistency across different working environments.

Another important position on CSR practices holds activities for social responsibility (community) by donating money, products, or services to social causes and nonprofits. Community engagement is one of the key pillars of corporate social responsibility, alongside the concern with the workplace, the marketplace, and the environment. Some businesses choose to support a local charity with financial contributions, sponsor a local event, organize clean-up events, volunteer in local schools or community projects and generally get involved in community based CSR related to their product or service. This lets them use their expertise and show the human face of their business at the same time.

The Marketplace pillar is related to the management of the relationship with its customers, suppliers, and business partners. Buying and selling products or services is a core part of a business and thus it should be ensuring that is done in an ethical and sustainable manner implementing rules of quality assurance. These rules should be followed through the supply chain and the idea of CSR must follow certain procedures of evaluation and recording complaints.

\subsection{Measurement of CSR (Bibliography Approach)}

Prior studies in different environmental management domains have predicted that customer satisfaction, reputation, and competitive advantage are three out- 
comes of CSR. Therefore, it is suggested that these elements should be taken into account in studies on the relationship between CSR and firm performance and identify the role of these variables e.g. (Alafi \& Alsufy, 2012; Galbreath \& Shym, 2012). According to Keh and Xie (2009), CSR is an essential element in developing and maintaining a favorable corporate reputation, which is regarded as an important strategic resource factoring into a company's competitive advantage. Therefore, many studies have experimentally confirmed this relationship (Brickley et al., 2002; Lai et al., 2010; Hsu, 2012). Thus consumers may hold different associations with brands because of CSR records according to Wu et al. (2014). In other words, initiatives for CSR assist a company in differentiating its products or service by creating a positive brand image, which safeguards the company's reputation.

Nevertheless, the most common use of a proxy for the independent variable of CSR is salaries and wages spending of employees, donation in the form of health and education, etc. Proxy was used by Kiran et al. (2015). It is common that researchers use different dimensions of CSR disclosure to examine the impact of CSR on CFP. For example, Ngwakwe (2009) used CSRD on Employee Health and Safety (EHS), Waste Management (WM) and Community Development (CD) meanwhile Mishra \& Suar (2010) used CSRD on employee, customer, supplier, community and environment dimension.

\subsection{Measurement of Financial Performance (Bibliography Approach)}

Though there is no real consensus on how to properly measure CFP, however, most measures of CFP divided into two broad categories; accounting-based measure according to Bayoud et al. (2012) and market-based measure according to Lioui \& Sharma (2012). There are also some researchers, such as Ehsan \& Kaleem (2012) that adopt both of these categories. On the other hand, following the precedent of the previous studies, the use of accounting-based measures has been received vast attention and mostly used by researcher. Among the accounting-based measures, Aupperle et al. (1985), Freedman \& Jaggi (1988), Waddock \& Graves (1997), Simpson \& Kohers (2002), the most widely used is the return on assets (ROA), the return on equity (ROE) and the return on sales (ROS), and among the market-based measures the most known are the market return, the price-to-earnings ratio and the market value to book value.

Accounting-based indexes of CFP indicate the past or short-term financial performance instead of market-based that captures future or long-term financial performance (Gentry \& Source, 2010). The proponents of accounting-based measures argue that market-based measures can be affected by several factors that are not related to the firm's activity (Platanova et al., 2018). However, the proponents of market-based measures dispute the objectivity of accounting figures and underline the measures related to shareholders and investors (Brammer \& Millington, 2008). 


\subsection{Hypothesis Development}

The main purpose of this paper is to detect for a significant relationship between CSR and CFP. Consequently, we analyze financial data from the corporate annual reports of listed firms as well as their stock prices.

It is common accepted that CSR practices are reflected in the annual reports as donations. Nevertheless, we noticed that donations for CSR are not reported individually in specific accounts due to the fact that firms are not obliged to report them. Dkhili \& Ansi (2012) and Ahamed et al. (2014) have mentioned the following different approaches to measuring CSR:

1) Content analysis by a measure of speech, which was based on content analysis of annual reports and specifically on remarks made by companies to assess their CSR activities. Examples of content analysis by counting the number of lines or words used for activities of CSR in the annual report of companies were Aras et al. (2010); Mwangi \& Oyenje (2013); Ngwakwe, 2009; Karagiorgos (2010).

2) Indicator of pollution, provided by some agencies to assess the pollution of businesses as for example measurements of diffusion of $\mathrm{CO}_{2}$ by businesses (Uwuigbe \& Egbide, 2012).

3) Measures of attitudes and values aimed at assessing the sensitivity of members of the organization. In those studies, CSR was measured using questionnaires (Bayoud et al., 2012; Mishra \& Suar, 2010).

4) The estimate of reputation, such as the indicator of reputation developed by Markowitz in the 1970s which includes criteria related to CSR.

5) The behavioral/audit approach assessed by the agencies that focus on the registration of behavior and environmental responsibility (Boesso et al., 2013; Lioui \& Sharma, 2012; Nelling \& Webb, 2008; Tench et al., 2012).

6) Donation or charity contribution by the companies estimated by the amount spent on the community, the environment, the employees, and the marketplace in aggregate due to multiple obligations derived from CSR (Karagiorgos, 2010). Prior studies (Ngwakwe, 2009) used CSRD on employee Health and Safety (EHS), Waste Management (WM) and Community Development (CD), while Mishra \& Suar (2010) adopted the CSRD on employee, customer, supplier, community, and environment dimension.

Hence, our approach doesn't use either indicators of reputation, pollution, or amounts of donations or other measures of environmental responsibility or other attributes and values using questionnaires. It is based on content analysis from the indication of activities written on sustainability reports and non-financial reports, divided into four pillars of CSR (environment, workplace, community, and marketplace). This approach provides more accurate and sufficient information for the CSR because it is not based on the financial reports in which the CSR relevant information is not clearly reported.

A critical point for this research was the choice of variables that attribute better in measuring financial performance. Among most researchers who typically used market or stock-based measure as CFP measurement (as already men- 
tioned in the bibliography CSR approach section 3.2) our point of view supported the stakeholder approach in CSR (Nikolova \& Arsic, 2017). More specifically, the analysis of variables in the used model is assessing not only accounting information but it is also based on the "the essence of CSR" which reflects the participation of the stakeholders.

The commonly identified stakeholder groups include shareholders (or owners) employees, customers, suppliers, local community, competitors, government, media, and society. Given the fact that the stakeholders are a key factor for the success of the CSR practices, the Q ratio of Tobin (Tobin's Q) was chosen as one of the dependent variables of our research.

Tobin's Q compares the stock value of a listed firm - which captures stakeholder behavior-with the value of their total assets. Therefore, Tobin's Q could be an important measure of intellectual capital as it can reflect the value markets place on assets, which are not normally reported in the conventional Balance Sheet.

As far as accounting based measurements, a short look at the related bibliography reveals the different approaches of indicators for the company's profitability. Matari et al. (2014), introduced two-mostly used-indicators and gauge the operating and financial performance of a firm. Although the rate of profit is measured by the accountant and is limited by standards established by the profession, ROA-which reflects the company's effective use of assets-and ROE-that calculates financial performance by dividing net income by shareholders' equity-are the most used account-based indices. Hence, according to Hutchinson \& Gull (2004), accounting-based performance indicators are preferred over the market-based ones because they reflect the management actions outcome.

Thus, in our research, we use ROA, ROE, and $\mathrm{Q}$ ratio to examine the relation between the effectively and efficiently management, the use of corporate asset and the inventory turnover and sales with firms CSR activities. This relation may have "double meaning" since it may reflect that firms that are activated in CSR have better financial performance or that firm exhibit superior financial performance will devote more resources for social responsibility. The CSR pillars have been selected as independent, categorical, variables.

Categorical regression quantifies categorical data by assigning numerical values to the categories, resulting in an optimal linear regression equation for the transformed variables. Thus, we converted the categorical variable CSR into a form that can be explained in regression analysis coding 1 for firms that disclose CSR activities and 0 for firms that don't disclose. The analysis was moderated and validated by including additional, moderator variables in calculations that have been found to influence or strengthen the relationship examined (Sharma, 1981). In this research, the moderator variables firm size and sales growth, and leverage are included in accordance with suggestions from several previous researchers of the CSR and Financial performance relationship (Ulmann, 1985; Waddock \& Graves, 1997; McWilliams \& Siegel, 2000; Hagberg et al., 2015).

In this research, we seek to answer in the question whether the CSR oriented firms become more valuable and profitable than of the firms with low CSR activ- 
ities. We also mentioned that the examined period of this research are the years 2016-2017 in which Greek economy has been stated under financial probation and also under the capital controls. Due to the fact that previous studies have not focused on relevant economies we contribute to the literature exploring the impact of CSR activity. In order to answer the research question we formulated the following hypotheses.

Hypothesis 1: There is a significant difference between CFP indicators of firms that report CSR activities and those which do not report.

Hypothesis 2: CSR activity and CSR pillars individually affect CFP indices.

Hypothesis 3: Better performing firms are more likely to adopt CSR practices.

\subsection{Model}

We applied the non-parametric test of Kruskal-Wallis to detect any significant difference in the medians of CFP variables between firms that reported CSR information and those who didn't. In recent studies, Christopoulos et al. (2019); Kalantonis et al. (2020), panel regression analysis has been used for multi-dimensional data of an observation that is measured repeatedly over time ${ }^{1}$, applied in financial accounting research. Nevertheless, we developed two regression equations using a categorical variable (CSR) and the financial corporate performance as explanatory variables, due to the fact that we focus on two years individually.

In the first one, we explored the effect of CSR on CFP. The effect of every individual CSR pillar on CFP was explained with the second equation. Categorical regression follows in order to estimate whether there is a correlation between financial performance and socially active firms. The proposed model to validate our objective is according to Kang and Liu (2013) as well as earlier studies on the subject (Agrawal \& Knoeber, 1996; Florackis et al., 2009; Li et al., 2009).

\section{First model}

Performance $_{i}=\beta_{0}+\beta_{1} \mathrm{CSR}_{-}$dummy $_{i}+\beta_{2}$ size $_{i}+\beta_{3}$ leverage $_{i}$

$$
+\beta_{4} \text { salesgrowth }_{i}+\text { year }_{i}+e_{i}
$$

\begin{tabular}{|c|c|}
\hline \multicolumn{2}{|c|}{ Dependent Variable Performance of firm $i$ as measured by: } \\
\hline ROA (\%) & Return on assets $=$ net income/total assets \\
\hline ROE (\%) & Return on equity $=$ net income/total equity \\
\hline TOBIN'S Q & Market value of a company divided by its assets' replacement cost \\
\hline & Independent variables \\
\hline CSR_dummy & $\begin{array}{l}\text { Dummy variable equals to } 1 \text { for companies which report CSR } \\
\text { activities and } 0 \text { otherwise }\end{array}$ \\
\hline Size & The natural logarithm of total assets \\
\hline Leverage & Total debt/total assets \\
\hline Sales annual growth (\%) & sales $_{2017} /$ sales $_{2016}$ \\
\hline Year & The examined year \\
\hline$e_{i}$ & error \\
\hline
\end{tabular}

${ }^{1}$ https://towardsdatascience.com/panel-data-regression-a-powerful-time-series-modeling-technique$7509 \mathrm{ce} 043 \mathrm{fa} 8$. 
In the following equation every individual CSR pillar has been added as independent variable.

\section{Second model}

Performance $_{i}=\beta_{0}+\beta_{1 . i} \mathrm{CSR} \_$pillar $_{i}+\beta_{2}$ size $_{i}+\beta_{3}$ leverage $_{i}$

$+\beta_{4}$ salesgrowth $_{i}+$ year $_{i}+e_{i}$

Independent variables

CSR_pillar Equal to 1 for the pillar that companies disclose and 0 otherwise

\section{Descriptive Statistics}

The collected data are briefly examined using descriptive statistics.

In Table 1, we present statistical measures of central tendency and variability for all the dependent variables. We observe that the mean value of ROA and ROE is positive even in the period of crisis. On the other hand, we indicate that the variability is high and that there is a gap between the mean and the median value for the year 2016. Moreover, the $\mathrm{Q}$ ratio is low for both of the two examined years. This is expected because of the low firms' share prices.

\section{Results \& Discussion}

In this paper, we selected the above 4 pillars that represent more accurately the frame of CSR. These are environment, workplace, community, and marketplace dimensions based on measurements of CSR references in their annual reports from 98 listed firms in Athens Exchange Market for the period 2016-2017. Under this context, we created the following Table 2 .

We observe in Table 2, in the first year of the EU directives-for CSR reporting-adoption, that firms which reported their CSR activities were more than the firms which they didn't report them. Nevertheless, we observed that the reporting of CSR activities have been increased in the next year. That could be an indicator of the compliance improvement in the next year.

Table 1. Descriptive Statistics.

\begin{tabular}{cccc}
\hline \multicolumn{3}{c}{ Descriptive Statistics } \\
\hline 2016 & Mean & St. Deviation & Median \\
\hline Dependent Variables & 0.0157 & 0.0547 & 0.1375 \\
\hline ROA (net income/total assets) & 0.0033 & 0.1837 & 0.0341 \\
ROE (net income/equity) & 0.3140 & 0.3653 & 0.1586 \\
TOBIN'S Q & & & \\
\hline 2017 & Mean & St. Deviation & Median \\
\hline Dependent Variables & 0.0180 & 0.0639 & 0.0117 \\
ROA (net income/total assets) & 0.0095 & 0.1645 & 0.0306 \\
ROE (net income/equity) & 0.3838 & 0.4514 & 0.2261 \\
\hline TOBIN'S Q & & &
\end{tabular}


Table 2. Tally for Discrete variables.

\begin{tabular}{cccccc}
\hline \multicolumn{5}{c}{ Tally for Discrete variables } \\
\hline Value & CSR & $\begin{array}{c}\text { CSR } \\
\text { Community }\end{array}$ & $\begin{array}{c}\text { CSR } \\
\text { Workplace }\end{array}$ & $\begin{array}{c}\text { CSR } \\
\text { Environment }\end{array}$ & $\begin{array}{c}\text { CSR } \\
\text { Marketplace }\end{array}$ \\
\hline 0 (not disclosed) & 41 & $55(56.1 \%)$ & $43(43.9 \%)$ & $43(43.9 \%)$ & $63(64.3 \%)$ \\
1 (disclosed) & 57 & $43(43.9 \%)$ & $55(56.1 \%)$ & $55(56.1 \%)$ & $35(35.7 \%)$ \\
$\mathrm{N}$ & 98 & & & & \\
\hline Value & CSR & CSR & CSR & CSR & CSR \\
\hline (not disclosed) & 19 & $48(49.0 \%)$ & $22(22.4 \%)$ & $22(22.4 \%)$ & $57(58.2 \%)$ \\
1 (disclosed) & 79 & $50(51.0 \%)$ & $76(77.6 \%)$ & $76(77.6 \%)$ & $41(41.8 \%)$ \\
N & 98 & & & & \\
\hline
\end{tabular}

More specifically, looking into Table 2, firms didn't implement uniformly the regulatory CSR framework for every individual pillar of CSR. In the year 2016, the CSR activities for the community were reported for less than the half of the firms in the sample. Subsequently, the relevant activities for the employees and the environment were disclosed from $56.1 \%$ of the examined firms. We believe that this is not an adequate proportion for the mandatory adoption of an EU directive. Even more, we notice the low percentage (35.7\%) of the market responsibility reporting. In other words, firms avoided presenting their CSR policy for their customers, suppliers the impact of products and services on the consumers, and the responsibility for the supply chain standards they apply.

Regarding 2017, the investigated firms emphasized more on the improvement of their responsibility for the environment and the employees' development, work-life balance, diversity, and health and safety. The disclosure of the CSR environment and CSR workplace increased approximately by $20 \%$. Unfortunately, the increase of the activities reporting for the society and the market was approximately measured in $7 \%$ and $6 \%$ respectively. However we must mention that the proportion of the firms which didn't report their CSR activities for the market components, remains lower than the $50 \%$ of the included firms in the total sample. In addition, we point that the relevant proportion of the CSR for the society wasn't increased as much as the total CSR, although it is marginally over $50 \%$.

As we have already stated, the first hypothesis of the current research tests for significant differences between the CFP indicators of firms that report their CSR activities and those of firms that didn't comply with the regulatory framework.

For that purpose, we test for the significant differences using the non-parametric means test of Kruskal-Wallis. This test is appropriate for not normally distributed variables and we didn't find any evidence for that using the Anderson-Darling test for normality. 
Summarizing the results in Table 3, we found significant evidence that the indices ROA, ROE, and Tobin's $\mathrm{Q}$ are higher for the firms which disclosed CSR reports in the year 2016 and that ROA and ROE are higher in the year 2017. Regarding the individual pillars, the $\mathrm{Q}$ ratio appeared significantly higher only for the year 2016. Specifically, at the level of significance less than $10 \%$, but more than $5 \%$, the median of the CSR activated firms is higher than the group of the non-activated. Nevertheless, the CSR activated firms are significant more profitable-in terms of ROA and ROE-than the non-activated for both of the years 2016 and 2017. The above findings don't necessarily mean that CSR reporting affects firms' profitability. Another approach on the meaning of the results presented in Table 3, could be that the more profitable firms report their CSR activities. In any case, CSR reporting seems to be related with profitability and in these terms, we couldn't reject the Hypothesis 3.

Table 3. Indices.

\begin{tabular}{|c|c|c|c|c|c|c|c|}
\hline & & \multicolumn{2}{|c|}{ Tobin's Q } & \multicolumn{2}{|c|}{ ROA } & \multicolumn{2}{|c|}{ ROE } \\
\hline & & Median & $p$-value & Median & $p$-value & Median & $p$-value \\
\hline \multicolumn{8}{|c|}{ CSR } \\
\hline \multirow{2}{*}{2016} & & 0.2207 & \multirow{2}{*}{$0.080^{\star}$} & 0.0190 & \multirow{2}{*}{0.006} & 0.0518 & \multirow{2}{*}{$0.001^{\star * *}$} \\
\hline & ND & 0.1388 & & 0.0003 & & 0.0004 & \\
\hline \multirow{2}{*}{2017} & $\mathrm{D}$ & 0.2346 & \multirow{2}{*}{0.805} & 0.0183 & \multirow{2}{*}{$0.015^{\star \star \star}$} & 0.0461 & \multirow{2}{*}{$0.011^{\star * \star}$} \\
\hline & ND & 0.2176 & & -0.0128 & & -0.0298 & \\
\hline \multicolumn{8}{|c|}{ CSR Community } \\
\hline \multirow{2}{*}{2016} & $\mathrm{D}$ & 0.1871 & \multirow{2}{*}{0.313} & 0.0190 & \multirow{2}{*}{$0.051^{\star \star}$} & 0.0518 & \multirow{2}{*}{$0.014^{* * *}$} \\
\hline & ND & 0.1494 & & 0.0063 & & 0.0244 & \\
\hline \multirow{2}{*}{2017} & $\mathrm{D}$ & 0.3230 & \multirow{2}{*}{0.339} & 0.0218 & \multirow{2}{*}{$0.052^{\star *}$} & 0.0520 & \multirow{2}{*}{$0.013^{* * *}$} \\
\hline & ND & 0.2051 & & 0.0058 & & 0.0082 & \\
\hline \multicolumn{8}{|c|}{ CSR Workplace } \\
\hline \multirow{2}{*}{2016} & $\mathrm{D}$ & 0.2207 & \multirow{2}{*}{$0.084^{\star}$} & 0.0190 & \multirow{2}{*}{$0.007^{\star \star *}$} & 0.0519 & \multirow{2}{*}{$0.001^{\star * *}$} \\
\hline & ND & 0.1388 & & 0.0039 & & 0.0049 & \\
\hline \multirow{2}{*}{2017} & $\mathrm{D}$ & 0.2422 & \multirow{2}{*}{0.993} & 0.0185 & \multirow{2}{*}{$0.008^{\star * *}$} & 0.0494 & \multirow{2}{*}{$0.003^{* * *}$} \\
\hline & ND & 0.2118 & & -0.0105 & & -0.0299 & \\
\hline \multicolumn{8}{|c|}{ CSR Environment } \\
\hline \multirow{2}{*}{2016} & $\mathrm{D}$ & 0.2207 & 0.129 & 0.0195 & $0002 * * *$ & 0.0518 & $0000 * * *$ \\
\hline & ND & 0.1394 & 0.127 & 0.0003 & 0.002 & 0.0004 & 0.000 \\
\hline 2017 & $\mathrm{D}$ & 0.2506 & 0.946 & 0.0180 & $0026^{* *}$ & 0.0460 & $0030 * *$ \\
\hline 2017 & ND & 0.2126 & 0.30 & -0.0090 & 0.020 & -0.0196 & 0.000 \\
\hline CSR M & place & & & & & & \\
\hline & $\mathrm{D}$ & 0.1779 & & 0.0195 & & 0.0580 & $0005 * * *$ \\
\hline 2016 & ND & 0.1523 & 0.419 & 0.0063 & $0.036^{2 \pi}$ & 0.0244 & 0.005 \\
\hline & $\mathrm{D}$ & 0.2521 & & 0.0218 & & 0.0542 & \\
\hline 2017 & ND & 0.2133 & 0.705 & 0.0034 & 0.024 & -0.0095 & 0.003 \\
\hline
\end{tabular}

*at a level of significance less than $10 \%,{ }^{* *}$ at a level of significance $5 \%,{ }^{* *}$ at a level of significance $1 \%$. 
In order to test the second hypothesis of the entire study, we introduced six categorical regression equations, in which $\mathrm{Q}$ ratio, ROA and ROE are the dependent variables for the years 2016, 2017 individually. The four CSR pillars are the independent variables in all the developed regression models. The findings of the equations are reported in Table 4.

As shown in Table 4, the CSR pillars have not any significant effect on financial performance as is reflected on $\mathrm{Q}$ ratio. There is only some evidence for significant impact that the CSR activities of the listed firms in 2017 affected on Q ratio. However, the proportion of variance in the $\mathrm{Q}$ ratio which was explained by all the CSR pillars is too low. Consequently, we couldn't argue that CSR activities have any impact on a market performance indicator. On the other side, CSR

Table 4. Categorical regression analysis.

\begin{tabular}{|c|c|c|c|c|c|c|}
\hline \multicolumn{7}{|c|}{ Categorical regression analysis } \\
\hline Year & $\begin{array}{l}\text { Dependent } \\
\text { variable }\end{array}$ & $\begin{array}{l}\text { Independent } \\
\text { Variables }\end{array}$ & $\begin{array}{c}\text { Coefficient } \\
\text { beta }\end{array}$ & $p$-value & $\begin{array}{c}\text { Sig. } \\
\text { ANOVA }\end{array}$ & $\begin{array}{l}\text { R-square } \\
\text { adjusted }\end{array}$ \\
\hline \multirow{4}{*}{2016} & \multirow{4}{*}{ TOBIN’S Q } & CSR community & 0.044 & 0.729 & \multirow{4}{*}{0.309} & \multirow{4}{*}{0.009} \\
\hline & & CSR workplace & 0.229 & 0.159 & & \\
\hline & & CSR environment & 0.012 & 0.916 & & \\
\hline & & CSR marketplace & 0.025 & 0.808 & & \\
\hline \multirow{4}{*}{2017} & \multirow{4}{*}{ TOBIN'S Q } & CSR community & 0.221 & 0.087 & \multirow{4}{*}{0.642} & \multirow{4}{*}{-0.015} \\
\hline & & CSR workplace & 0.135 & 0.231 & & \\
\hline & & CSR environment & 0.020 & 0.809 & & \\
\hline & & CSR marketplace & 0.055 & 0.558 & & \\
\hline \multirow{4}{*}{2016} & \multirow{4}{*}{ ROA } & CSR community & 0.244 & 0.095 & \multirow{4}{*}{0.028} & \multirow{4}{*}{0.072} \\
\hline & & CSR workplace & 0.048 & 0.770 & & \\
\hline & & CSR environment & 0.443 & 0.069 & & \\
\hline & & CSR marketplace & 0.131 & 0.323 & & \\
\hline \multirow{4}{*}{2017} & \multirow{4}{*}{ ROA } & CSR community & 0.055 & 0.724 & \multirow{4}{*}{0.041} & \multirow{4}{*}{0.102} \\
\hline & & CSR workplace & 0.163 & 0.234 & & \\
\hline & & CSR environment & 0.003 & 0.981 & & \\
\hline & & CSR marketplace & 0.251 & 0.094 & & \\
\hline \multirow{4}{*}{2016} & \multirow{4}{*}{ ROE } & CSR community & 0.244 & 0.333 & \multirow{4}{*}{0.072} & \multirow{4}{*}{0.050} \\
\hline & & CSR workplace & 0.016 & 0.970 & & \\
\hline & & CSR environment & 0.349 & 0.475 & & \\
\hline & & CSR marketplace & 0.179 & 0.454 & & \\
\hline \multirow{4}{*}{2017} & & CSR community & 0.036 & 0.797 & \multirow{4}{*}{0.052} & \multirow{4}{*}{0.057} \\
\hline & & CSR workplace & 0.336 & 0.093 & & \\
\hline & KUL & CSR environment & 0.202 & 0.251 & & \\
\hline & & CSR marketplace & 0.142 & 0.383 & & \\
\hline
\end{tabular}


activities for the society and for the environment affect significantly on ROA in the year 2016 and CSR activities for the market environment respectively in the year 2017 but the fitness of the regression model is extremely low. In addition, no significant effect of CSR pillars on ROE has been detected, except CSR activities for the human resources. However, also in those regression models the goodness of fit measured almost 5\%. According to these results, we cannot reject the second hypothesis of this research. Our results don't allow us to claim that CSR in total or in terms of individual pillars have any impact on firms' profitability, despite the fact that we detected some evidence in the opposite direction.

\section{Concluding Remarks}

The scope of this study was to explore the effect of modern business activities on firms' performance using accounting information. It is common accepted that sustainability and social responsibility are included in the priorities of the developed economies even, sometimes, there are conflicts with the environmental policies. Besides, sustainability is an increasingly important aspect of any country that has accepted the 17 life-changing goals, outlined by the UN in 2015 . These Global Goals, also known as the Sustainable Development Goals (SDGs), include ending extreme poverty, giving people better healthcare and achieving equality for women. We analyzed the financial information of the listed firms in the Athens Stock Exchange for two years period. Moreover, we used the stock prices of the listed firms.

As we stated in our empirical findings, the CSR activities were related to the profitability of firms. Obviously, we didn't find significant evidence for a specific effect of the CSR pillars on firms' profitability. Our findings are not relevant to those of previous studies (Bird et al., 2007; Bragdon \& Marlin, 1972; Waddock and Graves, 1997), which argued that there is a positive significant impact of CSR activities on firms' corporate profitability. Since, we observed that the reporting of CSR activities is related to the profitability of firms, we don't disagree with the findings of Li et al. (2013). The limited compliance with the law could mean that there is not adequate CSR awareness and possibly all the CSR pillars do not constitute a priority for business firms. We believe that only the law is not enough for firms to develop social responsibility culture. Previous studies indicated that the interest of firms in the stakeholders will finally generate profit for the firms. However, that profit would be difficult to be reported in the first years of CSR activities reporting.

\section{Limitations and Future Research Proposal}

The examined period was 2016-2017 in which the stock prices and the firms' profitability were low, as well as the Greek economy was stated under probation. Also, since the second half of 2015 firms faced liquidity problems because of the capital controls. All these facts could be limitations in our research which explain the limited interest for CSR activities reporting and especially the respon- 
sibility for the market environment and social responsibility activities. Furthermore, we believe that the CSR activities reports should be included in the financial reports. In this way, the reported information could be more accurate and reliable and consequently more interesting for the shareholders and stakeholders. After all, the CSR activities are reported in the integrated financial reports which are not still mandatory in Greece. We propose a further research on the investigation of the effect of CSR reporting on the improvement of financial reports. Last but not least, we consider that the level of the CSR pillars adoption should be studied in order to evaluate the CSR awareness and culture.

\section{Conflicts of Interest}

The authors declare no conflicts of interest regarding the publication of this paper.

\section{References}

Agrawal, A., \& Knoeber, R. C. (1996). Firm Performance and Mechanisms to Control Agency Problems between Managers and Shareholders. Journal of Financial and Quantitative Analysis, 31, 377-397. https://doi.org/10.2307/2331397

Ahamed, W. S. W., Almsafir, M. K., \& Al-Smadi, A. W. (2014). Does Corporate Social Responsibility Lead to Improve in Firm Financial Performance? Evidence from Malaysia. International Journal of Economies and Finance, 6, 126-138. https://doi.org/10.5539/ijef.v6n3p126

Alafi, K., \& Alsufy, F. (2012). Corporate Social Responsibility Associated with Customer Satisfaction and Financial Performance: A Case Study with Housing Banks in Jordan. International Journal of Humanities and Social Science, 2, 102-115.

Albertini, E. (2013). Does Environmental Management Improve Financial Performance? A Meta-Analytical Review. Organization \& Environment, 26, 431-457. https://doi.org/10.1177/1086026613510301

Aragon-Correa, A. J., \& Sharma, S. (2003). A Contingent Resource-Based View of Proactive Corporate Environmental Strategy. Academy of Management Review, 28, 71-88. https://doi.org/10.5465/amr.2003.8925233

Aras, G., Aybars, A., \& Kutlu, O. (2010). Managing Corporate Performance. International Journal of Productivity and Performance Management, 59, 229-254. https://doi.org/10.1108/17410401011023573

Astara, O.-E., Beneki, C., Mitoula, R., \& Kalantonis, P. (2017). Corporate Social Responsibility and Financial Performance within the Business Sector in Greece. In A. Kavoura, D. Sakas, \& P. Tomaras (Eds.), Strategic Innovative Marketing. Springer Proceedings in Business and Economics (pp. 337-345). Cham: Springer International Publishing. https://doi.org/10.1007/978-3-319-33865-1_43

Aupperle, K. E., Carroll, A. B., \& Hatfield, J. D. (1985). An Empirical Examination of the Relationship between Corporate Social Responsibility and Profitability. Academy of Management Journal, 28, 446-463.

Awang, Z. H., \& Jusoff, K. (2009). The Effects of Corporate Reputation on the Competitiveness of Malaysian Telecommunication Service Providers. International Journal of Business and Management, 4, 173-178. https://doi.org/10.5539/ijbm.v4n5p173

Babiak, K., \& Trendafilova, S. (2011). CSR and Environmental responsibility: Motives and Pressures to Adopt Green Management Practices. Corporate Social Responsibility and 
Environmental Management, 18, 11-24. https://doi.org/10.1002/csr.229

Baldwin, R., \& Giavazzi, F. (2015). The Eurozone Crisis: A Consensus View of the Causes and a Few Possible Solutions. London: CERP Press.

Bayoud, N. S., Kavanagh, M., \& Slaughter, G. (2012). An Empirical Study of the Relationship between Corporate Social Responsibility Disclosure and Organizational Performance: Evidence from Libya. International Journal of Management and Marketing Research, 5, 69-82.

Bhattacharyya, A., \& Rahman, M. L. (2019). Mandatory CSR Expenditure and Firm Performance. Journal of Contemporary Accounting and Economics, 15, Article ID: 100163. https://doi.org/10.1016/j.jcae.2019.100163

Bird, R., Hall, A., Momente, F., \& Reggiani, F. (2007). What Corporate Social Responsibility Activities Are Valued by the Market? Journal of Business Ethics, 76, 189-206. https://doi.org/10.1007/s10551-006-9268-1

Boesso, G., Kumar, K., \& Michelon, G. (2013). Descriptive, Instrumental and Strategic Approaches to Corporate Social Responsibility: Do They Drive the Financial Performance of Companies Differently? Accounting, Auditing and Accountability Journal, 26, 339-422. https://doi.org/10.1108/09513571311311874

Bragdon, H. J., \& Marlin, T. J. (1972). Is Pollution Profitable? Risk Management. Business and Society Review, 19, 9-18.

Brammer, S., \& Millington, A. (2008). Does It Pay to Be Different? An Analysis of the Relationship between Corporate Social and Financial Performance. Strategic Management Journal, 29, 1325-1343. https://doi.org/10.1002/smj.714

Brickley, J., Smith, C. W., \& Zimmerman, J. L. (2002). Business Ethics and Organizational Architecture. Journal of Banking \& Finance, 26, 1821-1835.

https://doi.org/10.1016/S0378-4266(02)00193-0

Cho, J. S., Chung, Y. C., \& Young, J. (2019). Study on the Relationship between CSR and Financial Performance. Sustainability, 11, 343. https://doi.org/10.3390/su11020343

Christopoulos, A. G., Dokas, I. G., Kalantonis, P., \& Koukkou, T. (2019). Investigation of Financial Distress with a Dynamic Logit Based on the Linkage between Liquidity and Profitability Status of Listed Firms. Journal of the Operation Research Society, 70, 1817-1829. https://doi.org/10.1080/01605682.2018.1460017

Dangelico, M. R., \& Pontrandolfo, P. (2015). Being "Green and Competitive": The Impact of Environmental Actions and Collaborations on Firm Performance. Business Strategy and the Environment, 24, 413-430. https://doi.org/10.1002/bse.1828

Davis, K. (1967). Understanding Social Responsibility Puzzle. Business Horizons, 10, 45-50. https://doi.org/10.1016/0007-6813(67)90007-9

Dkhili, H., \& Ansi, H. (2012). The Link between Corporate Social Responsibility and Financial Performance. The Case of the Tunisian Companies. Journal of Organizational Knowledge Management, 2012, Article ID: 640106.

Ehsan, S., \& Kaleem, A. (2012). An Empirical Investigation of the Relationship between Corporate Social Responsibility and Financial Performance. Journal of Basic and Applied Scientific Research, 2, 2909-2922.

Florackis, C., Kostakis, A., \& Ozkan, A. (2009). Managerial Ownership and Performance. Journal of Business Responsibility, 62, 1350-1357. https://doi.org/10.1016/j.jbusres.2008.12.001

Freedman, M., \& Jaggi, B. (1988). An Analysis of the Association between Pollution Disclosure and Economic Performance. Accounting, Auditing and Accountability Journal, 1, 43-58. https://doi.org/10.1108/EUM0000000004623 
Galbreath, J., \& Shym, P. (2012). Do Customer Satisfaction and Reputation Mediate the CSR-FP Link? Evidence from Australia. Australian Journal of Management, 37, 211-229. https://doi.org/10.1177/0312896211432941

Gentry, J., \& Source, W. S. (2010). The Relationship between Accounting and Market Measures of Firm Financial Performance: How Strong Is It? Journal of Managerial Issues, 22, 514-530.

Hagberg, C., Johansson, S., \& Karlsson, A. (2015). The Relationship between CSR and Financial Performance: A Quantitative Study Examining Swedish Publicly Traded Companies. Sweden: Linnaeus University.

Halila, F., \& Rundquist, J. (2011). The Development and Market Success of Eco-Innovations. European Journal of Innovation Management, 14, 278-302. https://doi.org/10.1108/14601061111148807

Hardouvelis, A. G., \& Gionis, I. (2016). A Decade long Economic Crisis: Cyprus versus Greece. Cyprus Economic Policy Review, 10, 3-40.

Hategan, C.-D., Curea, R., \& Hategan, V.-P. (2018). Doing Well of Doing Good: The Relationship between Corporate Social Responsibility and Profit in Romanian Companies. Sustainability, 10, 1041. https://doi.org/10.3390/su10041041

Hsu, T. K. (2012). The Advertising Effects of Corporate Social Responsibility on Corporate Reputation and Brand Equity: Evidence from the Life Insurance Industry in Taiwan. Journal of Business Ethics, 109, 189-201.

https://doi.org/10.1007/s10551-011-1118-0

Hutchinson, M., \& Gull, F. (2004). Investment Opportunity Set, Corporate Governance Practices, and Firm Performance. Journal of Corporate Finance, 10, 595-614. https://doi.org/10.1016/S0929-1199(03)00022-1

Kakakhel, S. J., Ilyas, M., Iqbal, J., \& Afeef, M. (2015). Impact of Corporate Social Responsibility on Financial Performance: Evidence from Pakistan's Cement Industry. Abasyn Journal of Social Sciences, 8, 392-404.

Kalantonis, P., Schoina, S., Missiakoulis, S., \& Zopounidis, C. (2020). The Impact of the Disclosed R \& D Expenditure on the Value Relevance of the Accounting Information: Evidence from Greek Listed Firms. Mathematics, 8, 730. https://doi.org/10.3390/math8050730

Kang, H.-H., \& Liu, S.-B. (2013). Corporate Social Responsibility and Corporate Performance: A Quantile Regression Approach. Quality \& Quantity, 48, 3311-3325. https://doi.org/10.1007/s11135-013-9958-6

Karagiorgos, T. (2010). Corporate Social Responsibility and Financial Performance: An Empirical Analysis on Greek Companies. European Research Studies, 13, 85-108. https://doi.org/10.35808/ersj/301

Keh, H. T., \& Xie, Y. (2009). Corporate Reputation and Customer Behavioral Intentions: The Roles of Trust, Identification and Commitment. Industrial Marketing Management, 38, 732-742. https://doi.org/10.1016/j.indmarman.2008.02.005

Kiran, S., Kakakhel, S. J., \& Shaheen, F. (2015). Corporate Social Responsibility and Firm Profitability: A Case of Oil and Gas Sector of Pakistan. City University Research Journal, 5, 110-119.

Koo, C., Chung, N., \& Ryoo, Y. S. (2014). How Does Ecological Responsibility Affect Manufacturing Firms' Environmental and Economic Performance? Total Quality Management \& Business Excellence, 25, 1171-1189. https://doi.org/10.1080/14783363.2013.835615

Lai, C.-S., Chiu, C.-J., Yang, C.-F., \& Pai, D.-C. (2010). The Effects of Corporate Social 
Responsibility on Brand Performance: The Mediating Effect of Industrial Brand Equity and Corporate Reputation. Journal of Business Ethics, 95, 457-469.

https://doi.org/10.1007/s10551-010-0433-1

Lee, S., Signal, M., \& Kang, K. H. (2013). The Corporate Social Responsibility-Financial Performance Link in the U.S. Restaurant Industry: Do Economic Conditions Matter? International Journal of Hospitality Management, 32, 2-10.

https://doi.org/10.1016/j.ijhm.2012.03.007

Li, Q., Luo, W., Wang, Y., \& Wu, L. (2013). Firm Performance, Corporate Ownership and Corporate Social Responsibility Disclosure in China. Business Ethics, 22, 159-173. https://doi.org/10.1111/beer.12013

Li, T., Sun, L., \& Zou, L. (2009). State Ownership and Corporate Performance: A Quantile Regression Analysis of Chinese Listed Companies. China Economic Review, 20, 703-716. https://doi.org/10.1016/j.chieco.2009.05.006

Lioui, A., \& Sharma, Z. (2012). Environmental Corporate Social Responsibility and Financial Performance: Disentangling Direct and Indirect Effects. Ecological Economics, 78, 100-111. https://doi.org/10.1016/j.ecolecon.2012.04.004

Matari, A., Swidi, M. E., Al, K. A., \& Fadzil, B. F. (2014). The Measurements of Firm Performance's Dimensions. Asian Journal of Finance \& Accounting, 6, 24-49.

https://doi.org/10.5296/ajfa.v6i1.4761

McWilliams, A., \& Siegel, D. (2000). Corporate Social Responsibility and Financial Performance: Correlation or Misspecification? Strategic Management Journal, 21, 603-609. https://doi.org/10.1002/(SICI)1097-0266(200005)21:5<603::AID-SMJ101>3.0.CO;2-3

Mishra, S., \& Suar, D. (2010). Does Corporate Social Responsibility Influence Firm Performance of Indian Companies? Journal of Business Ethics, 95, 571-601. https://doi.org/10.1007/s10551-010-0441-1

Mwangi, C. I., \& Oyenje, J. J. (2013). The Relationship between Corporate Social Responsibility Practices and Financial Performance of Firms in the Manufacturing, Construction and Allied Sector of the Nairobi Securities Exchange. International Journal of Business, Humanities and Technology, 3, 81-90.

Nelling, E., \& Webb, E. (2008). Corporate Social Responsibility and Financial Performance: The "Virtuous Circle" Revisited. Review of Quantitative Finance and Accounting, 32, 197-209. https://doi.org/10.1007/s11156-008-0090-y

Nelson, M. R., Belkin, P., \& Jackson, K. J. (2015). The Greek Debt Crisis: Overview and implications for the United States. Washington: Federation of American Scientist Publication.

Ngwakwe, C. (2009). Environmental Responsibility and Firm Performance: Evidence from Nigeria. International Journal of Humanities and Social Sciences, 3, 97-104.

Nikolova, V., \& Arsic, S. (2017). The Stakeholder Approach in Corporate Social Responsibility. Engineering Management, 3, 24-35.

Ntanos, S., Kyriakopoulos, G., Chalikias, M., Arabatzis, G., \& Skordoulis, M. (2018). Public Perceptions and Willingness to Pay for Renewable Energy: A Case Study from Greece. Sustainability, 10, 687. https://doi.org/10.3390/su10030687

Ntanos, S., Kyriakopoulos, G., Skordoulis, M., Chalikias, M., \& Arabatzis, G. (2019). An Application of the New Environmental Paradigm (NEP) Scale in a Greek Context. Energies, 12, 239. https://doi.org/10.3390/en12020239

Platanova, E., Asutay, M., Dixon, R., \& Mohammad, S. (2018). The Impact of Corporate Social Responsibility Disclosure on Financial Performance: Evidence from the GCC Islamic Banking Sector. Journal of Business Ethics, 151, 451-471. 
https://doi.org/10.1007/s10551-016-3229-0

Porter, E. M., \& van der Linde, C. (1995). Toward a New Conception of the Environment-Competitiveness Relationship. Journal of Economic Perspectives, 9, 97-118. https://doi.org/10.1257/jep.9.4.97

Rexhauser, S., \& Rammer, C. (2014). Environmental Innovations and Firm Profitability: Unmasking the Porter Hypothesis. Environmental and Resource Economics, 57, 145-167. https://doi.org/10.1007/s10640-013-9671-x

Rhou, Y., Singal, M., \& Koh, Y. (2016). CSR and Financial Performance: The Role of CSR Awareness in the Restaurant Industry. International Journal of Hospitality Management, 57, 30-39. https://doi.org/10.1016/j.ijhm.2016.05.007

Saeidi, S. P., Sofian, S., Saeidi, P., Saeidi, S. P., \& Saaeidi, S. A. (2014). How Does Corporate Social Responsibility Contribute to Firm Financial Performance? The Mediating Role of Competitive Advantage, Reputation, and Customer Satisfaction. Journal of Business Research, 68, 341-350. https://doi.org/10.1016/j.jbusres.2014.06.024

Sharma, V. (1981). A Class of Experimental Designs Balanced for First Residuals. Australian Journal of Statistics, 23, 365-370. https://doi.org/10.1111/j.1467-842X.1981.tb00800.x

Simpson, G. W., \& Kohers, T. (2002). The Link between Corporate Social and Financial Performance: Evidence from the Banking Industry. Journal of Business Ethics, 35, 97-109. https://doi.org/10.1023/A:1013082525900

Skordoulis, M., Arabatzis, G., Chalikias, M., Ntanos, S., Glatsidas, S., \& Drosos, D. (2020a). Managers' Perceptions on Environmental Sustainability. Proceedings of the 9th International Conference on ICT in Agriculture, Food and Environment, Thessaloniki, September 2020, 407-415.

Skordoulis, M., Ntanos, S., \& Arabatzis, G. (2020b). Socioeconomomic Evaluation of Green Energy Investments: Analyzing Citizens' Willingness to Invest in Photovoltaics in Greece. International Journal of Energy Sector Management, 14, 871-890. https://doi.org/10.1108/IJESM-12-2019-0015

Skordoulis, M., Ntanos, S., Kyriakopoulos, L. G., Arabatzis, G., Galatsidas, S., \& Chalikias, M. (2020c). Environmental Innovation, Open Innovation Dynamics and Competitive Advantage of Medium and Large-Sized Firms. Journal of Open Innovation: Technology, Market, and Complexity, 6, 195. https://doi.org/10.3390/joitmc6040195

Tench, R., Sun, W., \& Jones, B. (2012). The Challenging Concept of Corporate Social Irresponsibility: An Introduction, In R. Tench, W. Sun, \& B. Jones (Eds.), Corporate Social Irresponsibility: A Challenging Concept (Critical Studies on Corporate Responsibility, Governance and Sustainability, Vol. 4) (pp. 3-20). Bingley: Emerald Group Publishing Limited. https://doi.org/10.1108/S2043-9059(2012)0000004009

Ulmann, A. (1985). Data in Search of a Theory: A Critical Examination of the Relationships among Social Performance, Social Disclosure, and Economic Performance of U.S. Firms. Academy of Management Review, 10, 540-557. https://doi.org/10.5465/amr.1985.4278989

Uwuigbe, U., \& Egbide, C. B. (2012). Corporate Social Responsibility Disclosures in Nigeria: A Study of Listed Financial and Non-Financial Firms. Journal of Management and Sustainability, 2, 160-169. https://doi.org/10.5539/jms.v2n1p160

Verma, L. (2015). Impact of Corporate Social Responsibilities in Modern Business Environment. International Journal of Scientific and Research Publications, 5, 1-4.

Waddock, S. A., \& Graves, S. B. (1997). The Corporate Social Performance-Financial Performance Link. Strategic Management Journal, 18, 303-319.

https://doi.org/10.1002/(SICI)1097-0266(199704)18:4<303::AID-SMJ869>3.0.CO;2-G 
Wang, Q., Dou, J., \& Jia, S. (2015). A Meta-Analytic Review of Corporate Social Responsibility and Corporate Financial Performance: The Moderating Effect of Contextual Factors. Business \& Society, 55, 1083-1121.

Waworuntu, R. S., Wantah, M. D., \& Rusmanto, T. (2014). CSR and Financial Performance Analysis: Evidence from top ASEAN Listed Companies. Procedia-Social and Behavioral Sciences, 164, 493-500. https://doi.org/10.1016/j.sbspro.2014.11.107

Wu, Q., He, Q., \& Duan, Y. (2014). Dynamic Capabilities for CSR Management towards Identifying Common Processes. Society and Business Review, 9, 276-297.

https://doi.org/10.1108/SBR-01-2013-0010 